Frank L. Schäfer, Prof. Dr., LL.M. (Cambridge)

Director of the Institute for Legal History and Comparative Legal History at Freiburg

University, Germany

\title{
TRANSITION FROM FEUDAL TO MODERN SOCIETY: THE IMPACT OF ABOLITION OF SERFDOM ON GERMAN PRIVATE LAW
}

\section{PĀREJA NO FEODĀLĀS UZ MŪSDIENU SABIEDRĪBU: DZIMTBŪŠANAS ATCELŠANAS IETEKME UZ VĀCIJAS PRIVĀTAJĀM TIESİBĀM}

\begin{abstract}
Kopsavilkums
Pētijjums veltìts dzimtbūšanas atcelšanai Svētās Romas impērijas un vēlāk Vācijas Konfederācijas vāciski runājošajās teritorijās. Dzimtbūšanas atcelšana nebija atsevišķs notikums, bet gan lielo sabiedrisko un ekonomisko pārmaiņu sastāvdaļa. Lauku apvidos dzimtbūšanas atcelšana ievērojami veicināja mūsdienu privāttiesību, jo īpaši nekustamā ipašuma likuma, attīstību.
\end{abstract}

Atslēgvārdi: dzimtbūšana, dzimtcilvēks, brīvība, vienlīdzība, privātās tiesības

\begin{abstract}
Summary
The study is devoted to the abolition of serfdom in the German-speaking territories of the Holy Roman Empire and later German Confederation. The abolition of serfdom was not an isolated event, but part of the great transformations in society and economy. In rural areas, the abolition contributed significantly to the development of modern private law, in particular real estate law.
\end{abstract}

Keywords: serfdom, hereditary subservience, liberty, equality, private law

\section{Introduction: Rural inequality of the Old Empire}

For today's private law, the formal equality of all people as subjects appears to be a natural matter. Public law supplements this formal equality with a more or less efficient and rational redistribution, which, depending on the political orientation, aims to a certain extent to achieve the material equality of citizens. The principle of formal equality is an integral part of modern private law theory and is based on the preparatory work of the freedom-loving laws of nature and reason of early modern times. a particularly important result of this equality is the equal legal capacity of all citizens. Its history began more than 200 years ago. ${ }^{1}$ The great codifications of civil law around 1800, the French Code Civil (1804) and the Austrian General Civil Code (1811/1812)

See Paulus C. Ein Plädoyer für unscheinbare Normen. Juristische Schulung, 1994, 367 (367 sq.); Stolleis M. Historische und ideengeschichtliche Entwicklung des Gleichheitssatzes. In: Gleichheit 
eliminated the legal differentiations between social classes and thus the hierarchical model of society from private law. ${ }^{2}$ The two codifications thus unravelled private law and public law and gave private law its present, slim form compared to the old ius privatum, a hybrid complex of norms with elements of modern private law and administrative law. However, legal (formal) inequality had not completely disappeared from the legal realm. Until 1918, the conservative forces in the German Empire were concentrated in public law and in secondary matters under private law such as the fideicommissum.

Only a few years before the first two modern codes of civil law, the General Land Law for the Prussian States had still cemented the legal inequality of classes. Although this code had formally abolished serfdom ${ }^{3}$ as a legal concept (part 2, title 7, $\$ 148$ ), it preserved the legal discrimination of peasants. Serfdom had been the central element of the agricultural constitution of rural areas in the Holy Roman Empire, the manorial system (Grundherrschaft). Serfdom as legal institution contained elements of personal law, law of obligations and property law as well as public law. This old law was highly segmented according to social classes and hierarchically structured. ${ }^{4}$

The present study focuses on the serfdom in the German-speaking territories of the late Holy Roman Empire and the subsequent German Confederation. The aim is to clarify the effects of the liberation of peasants (Bauernbefreiung) on the private law of the $19^{\text {th }}$ century, which forms the basis of our modern German private law. Methodically, the study pursues a comparative perspective almost inevitably, since the innumerable German territories organized serfdom (called hereditary subservience, Erbuntertänigkeit, in Prussia), the liberation of peasants and the following transformation and compensation very differently. From the point of view of European legal history, the legal history of the German-speaking territories of the Holy Roman Empire appears as a kind of legal subcontinent. The empire outwardly embraced the history of law, but the numerous legal systems of the individual territories differed quite considerably. Therefore, one can speak of a legal patchwork to describe the legal particularism figuratively.

In southwestern Germany, serfdom was comparatively mild towards the end of the early modern period. The restrictions on freedom of movement and marriage continued to restrict personal freedom. However, annual payments and a death levy replaced the hated corvée (Frondienst). The serfs cultivated their own fields. Serfdom was essentially an intensified form of taxation. In the north and east (Schleswig and

und Nichtdiskriminierung im nationalen und internationalen Menschenrechtsschutz, Berlin et al.: Springer, 2003, pp. 7-22.

2 Overview: Coing H. Europäisches Privatrecht. Vol. 2. Munich: Beck 1989, pp. 284-286; Duve T. S\$ 1-14, Natürliche Personen, Verbraucher, Unternehmer, marginal no. 6-10. In: Historischkritischer Kommentar zum BGB, Vol. 1, Tübingen: Mohr 2003, pp. 171-177.

3 Overview: Wunder H. Serfdom in Later Medieval and Early Modern Germany. In: Social Relations and Ideas: Essays in Honour of R. H. Hilton. Cambridge: Cambridge University Press 1983, pp. 249-272; specifically to individual territories: Freedmann P., Bourin M. (eds.). Forms of Servitude in Northern and Central Europe: Decline, Resistance, and Expansion. Turnhout: Brepols 2005. Part III: The German Case.

4 Leiser W. Schichtspezifisches Privatrecht. Savigny-Zeitschrift für Rechtsgeschichte. Germanistische Abteilung, Vol. 93, 1976, pp. 1-20. 
Holstein, West- and Eastphalia, the large territories of East Elbia) serfdom was much harder and the degree of freedom restriction much greater. Work duties in the form of corvée and menial service (Gesindezwang) were common. Especially the East Elbia landlords (lords of the manor, Grundherren) took all liberties from the peasants and forced them onto their manors as almost lawless servants. This is why this sharpest form of serfdom is called manor rule (Gutsherrschaft). The differences can still be felt today: here - the rich southwest Germany, there - the poor north and east.

The legal situation of peasant land also varied greatly, although it can be summarised under the ancient term of the so-called interest property (Zinsgut), in order to describe the recurring monetary charges of serfdom. It ranged from the full ownership of the serf (with simultaneous personal bondage) to split property between landlord and serf (dominium directum and dominium utile) to a mere leasehold-like entitlement. To the extent that the serfs were integrated into the landlord's estate, they were of course not entitled to any rights on the land. However, it would be anachronistic at this point to distinguish between a right in rem and an entitlement under the law of obligations only. The agricultural constitution of the early modern period did not draw a clear dividing line, since the personal ties of the serfs overlaid the entitlement on the ground. Even full ownership could not be equated with the full mobility of an agricultural property. Possession and legitimate ownership were therefore not categorical opposites either.

\section{Change in the law of persons}

The abolition of serfdom as personal inequality and unfreedom of the rural population is initially a phenomenon that can be described chronologically. ${ }^{5}$ In $1781 / 82$, Austria began to abolish serfdom in the entire realm. The Margraviate of Baden followed in 1783, the Duchies of Schleswig and Holstein from 1796 on, the Kingdom of Prussia in 1807, the Kingdoms of Bavaria and Westphalia in 1808, the Principality of Lippe in 1808, the Duchy of Nassau in 1808, the Grand Duchy of Hesse in 1811, the Duchy of Oldenburg in 1814, the Duchies of Mecklenburg from 1816 on and the Kingdom of Württemberg in 1817. The Kingdoms of Saxony and Hannover abolished serfdom as the last German territories in 1832 and 1833. The list documents the enactment of statutes to abolish serfdom. In individual cases such as Prussia, several years lay between the act itself (November Edict 1807) and the abolition of serfdom (on Martin's Day 1810). The whole process of abolition took about half a century. The beginnings go back to the final phase of the Holy Roman Empire, to the Age of Enlightenment. The majority of the liberation laws concentrated on the years after the end of the Holy Roman Empire, a phase of greatest uncertainty. The late legislation extended into the period after the great European revolutionary year of 1830 .

The legal justification for the abolition of serfdom was already indicated at the beginning with natural law. The transformation of the feudal system into the modern

Overview: Andermann K. Article Leibeigenschaft. In: Handwörterbuch zu deutschen Rechtsgeschichte. Vol. 3, Berlin: Erich Schmidt 2016, cols. 771-777. 
administrative state added a further constitutional argument. ${ }^{6}$ Serfs should not be burdened twice by the landlord with money payment and work duties and by the state with taxes and conscription. There were also very diverse practical reasons. The landlords hoped that the abolition would increase the productivity of their own large agricultural farms, while the sovereigns hoped, on their part, to win new taxpayers through direct access to the rural population, whereas the early industrial bourgeoisie with its liberal demands gave the decisive impulse.

\section{Transformation legislation and change in real estate law}

Three very different examples (the Kingdoms of Württemberg, Saxony and Prussia) ${ }^{7}$ will shed light on the problems that followed after the abolition of serfdom. Despite the new personal freedom of the former serfs, the question remained as to how the legal relationship should be structured between former landlords and serfs. The central questions were as follows: (1) Which ancient burdens are of a privatelaw nature and which are of a public-law nature? In the first case, the former serf or, subsidiarily, the state had to compensate the former landlord, in the second case not. (2) Who should now be entitled to the fully marketable land? Should it be the state, the former landlord or the former serfs? The first question concerns transformation costs, i.e. the iustitia commutativa, the second question the allocation of goods, i.e. the iustitita distributiva. Since compensatory justice is not a core principle of private law, principles of public law were applied in the redistribution of land.

In Württemberg, the transformation took place over a long period (from 1817 to 1873) and with a differentiation between the state as landlord and other persons as landlords. ${ }^{8}$ The focus was on compensation, less on the redistribution of agricultural land. Initially, Württemberg relied on voluntary agreements. There was no obligation to convert serfdom; the amount of the compensation was alone in the hands of the parties. ${ }^{9}$ Later, the legislature set a deadline for amicable settlement or shifted the choice to the serfs. ${ }^{10}$ As time went by, compensation schemes became more concrete and freedom of choice disappeared. Likewise, more and more the municipalities ${ }^{11}$ and the state ${ }^{12}$ took over the compensation. However, the legislation adhered to the

6 Hauser A. Die Gesetzgebung zur Herstellung unbeschränkten Grundeigentums und zur Aufhebung der Leibeigenschaft. Der württembergische Weg. Tübingen: Köhler-Druck 2003, pp. 39 sq.

7 Overview, also for other territories: Dipper C. Die Bauernbefreiung in Deutschland 1790-1850. Stuttgart et al.: Kohlhammer 1980, pp. 50-93.

8 In Detail Hauser A., pp. 81-183; Hippel W. Die Bauernbefreiung im Königreich Württemberg. Harald Boldt: Boppardt am Rhein 1977.

9 Rescript. Concerning allodification of fiefdoms. 6 July 1812. Royal Württemberg State and Government Gazette 1812, abridged edition, p. 154.

10 Ordinance. 13 September 1818. Royal Württemberg State and Government Gazette, 1818, p. 503.

11 Art. 3. Act. Concerning the removal of charges resting on the land. 14 April 1848. Government Gazette for the Kingdom of Württemberg, 1848, p. 165; Art. 6. Act. Concerning the replacement of tithes. 17 June 1849. Government Gazette for the Kingdom of Württemberg, 1849, p. 181.

12 Order. In reference to the latest compensation laws. 29 October 1836. Government Gazette for the Kingdom of Württemberg 1836, p. 588. 
principle of full compensation at least before the revolution of $1848 / 1849$, since Württemberg classified the rights arising from manorial rule and serfdom as individual property rights. To the extent that the state and no private person had been a formerly entitled landlord, either no or only a lower compensation was to be paid. ${ }^{13}$

Saxon legislation concentrated on only a few laws, since Saxony did not abolish serfdom until 1832 and could thus profit from legislative models in other territories. However, the state had already supported the voluntary termination of serfdom before. ${ }^{14}$ As in Württemberg, the focus was on compensation, less on the redistribution of agricultural land, since the peasants already cultivated 77 percent of the land on their own. ${ }^{15}$ Compensation was comprehensive, but regulated in detail by law from the outset, which favoured legal certainty. ${ }^{16}$ Therefore, the legislator only had to make minor corrections in the subsequent period. ${ }^{17}$ After the revolution of $1848 / 1849$, the legislator eased the compensatory payments, partially assigned the compensation obligation to the state and later let the still existing obligations expire without compensation. ${ }^{18}$

The Prussian transformation was much more extensive than in Württemberg and Saxony, since the landlords dominated agriculture with their large estates in East Elbia. ${ }^{19}$ Therefore, the redistribution problem was much more pressing here. The edict of 1811 deserves special mention. ${ }^{20}$ The statute dictated that former serfs had to sacrifice one third, sometimes even half, of their leased land in order to acquire full ownership. The law of 1850 on compensation and regulation of land, which abolished the legal institution of the dominium directum, was comparatively late. ${ }^{21}$ At the end, the landlords were the winners; they were able to considerably increase their cultivated areas in relation to their former serfs. ${ }^{22}$

13 Edict. 18 November 1817. Royal Württemberg State and Government Gazette 1817, appendix.

14 Groß R. Die bürgerliche Agrarreform in Sachsen in der ersten Hälfte des 19. Jahrhunderts. Untersuchung zum Problem des Übergangs vom Feudalismus zum Kapitalismus in der Landwirtschaft. Weimar: Hermann Böhlau, 1968, p. 77.

15 Groß R. Die bürgerliche Agrarreform in Sachsen und die sächsische Oberlausitz. Letopis, Series B, Vol. 14.1, 1967, p. 1 (18).

16 Act. On Redundancies and Common Divisions. 17 March 1832. Collection of Laws and Regulations for the Kingdom of Saxony, 1832, p. 163.

17 Groß R. Die bürgerliche Agrarreform in Sachsen in der ersten Hälfte des 19. Jahrhunderts. Untersuchung zum Problem des Übergangs vom Feudalismus zum Kapitalismus in der Landwirtschaft. Weimar: Hermann Böhlau, 1968, pp. 112-115.

18 Ibid., pp. 119 sq.

19 In Detail Knapp G. F. Die Bauern-Befreiung und der Ursprung der Landarbeiter in den älteren Teilen Preußens. 2 vols. Duncker \& Humblot: Leipzig, 1887.

20 Edict. Concerning the regulation of the property and peasant relations, 14 September 1811. Collection of Laws for the Royal Prussian States, 1811, p. 281.

21 Act. Concerning the compensation of land charges and the regulation of the landowner's and peasant's relationships. 2 March 1850. Collection of Laws for the Royal Prussian States, 1850, p. 77.

22 For exact numbers: Harnisch H. Kapitalistische Agrarreform und Industrielle Revolution. Agrarhistorische Untersuchungen über das ostelbische Preußen zwischen Spätfeudalismus und bürgerlich-demokratischer Revolution von 1848/49 unter besonderer Berücksichtigung der Provinz Brandenburg Weimar: Hermann Böhlau, 1984, pp. 186-252; Koselleck, Preußen zwischen Reform und Revolution, Stuttgart, 1967, pp. 498-502. 


\section{Importance for the history of private law}

The abolition of serfdom fits into the wider context of the progress of civilization since the French Revolution. The epoch of the early modern era came to an end; a new epoch began which we call modernity and in which we still live. This tremendous shift began with the early industrialization of Britain, population growth and political change brought about by American independence and the French Revolution. On the basis of the laws of nature and reason, the first national constitutions were established that guaranteed individual freedoms and thus protected private law against state interference for the first time. The constitutional state replaced the feudal state, and industrial society replaced agrarian society with its manorial system.

The transition from early modern times to modernity did not take place suddenly through a single event like the French Revolution, but through a whole chain of selective events and prolonged processes. It would be therefore a mistake to speak of a revolution as a whole. Rather, early modern times and modernity are linked by a phase of sometimes faster and slower change that can be traced between 1750 with British early industrialization and 1850 with the failed revolution of $1848 / 1849$. German historians have described this phase of transformation with the metaphor "saddle time" (Sattelzeit), which should remind of a mountain saddle, i.e. the transition between two larger objects. For the history of private law, however, a transition period of around 100 years would be too long. From the point of view of private law, the transition only begins with Gustav Hugo's "Institutions of Modern Roman Law" (Institutionen des heutigen Römischen Rechts) of 1789, i.e. with the beginning of the French Revolution. For the history of private law, the transformation phase already ended in 1815 with the first volume of the "Journal for Historical Legal Science" (Zeitschrift für geschichtliche Rechtswissenschaft), the quasi-official organ of the Historical School of Law, i.e. with the Congress of Vienna. Thus, the transitional period shrinks to a quarter of a century. From this perspective, the last legislative acts to abolish serfdom after 1815 are to be classified as a delayed liberation.

Marxist historiography interprets the abolition of serfdom not as peasant liberation, but as a transition from feudal to capitalist servitude. ${ }^{23}$ This historiography concentrates one-sidedly on land ownership and social conditions. The constitutional history will also be able to derive a certain degree of plausibility from this interpretation. Indeed, it cannot be denied that in many German states the peasants could not acquire full ownership of the land or manage the once acquired agricultural property in such a way that they had a sufficient income from it. The impoverished and wealthless masses migrated to the new industrial cities. In this way, the end of serfdom promoted the transformation of agrarian society into industrial society.

23 Paradigmatic: Harnisch H. Kapitalistische Agrarreform und Industrielle Revolution. Agrarhistorische Untersuchungen über das ostelbische Preußen zwischen Spätfeudalismus und bürgerlich-demokratischer Revolution von 1848/49 unter besonderer Berücksichtigung der Provinz Brandenburg Weimar: Hermann Böhlau, 1984, pp. 350-354; far more neutral: Groß R. Die bürgerliche Agrarreform in Sachsen in der ersten Hälfte des 19. Jahrhunderts. Untersuchung zum Problem des Übergangs vom Feudalismus zum Kapitalismus in der Landwirtschaft. Weimar: Hermann Böhlau, 1968, passim. 
However, the history of private law must decisively counter this interpretation of history. ${ }^{24}$ From the point of view of liberal private law, one can speak of three new fundamental freedoms or liberation processes: the introduction of freedom of occupation, the liberation of peasants (Bauernbefreiung), ${ }^{25}$ and land mobilisation (Bodenmobilisierung). With the formal equality of all citizens, landlord and serf disappeared from the legal order. They were replaced by the farmer who managed the land as a noble, middle-class or peasant entrepreneur. Three aspects in particular deserve special mention:

(1) The liberation of peasants helped to separate the law of persons from the law of obligations and property law, thus paving the way for the modern division of private law. In the early modern period, the assignment had often been very difficult; the corvée is exemplary here. In Württemberg, corvée could be designed both as a right in rem or as a personal bond from serfdom. ${ }^{26}$ The same conclusion applies in the broader context to the distinction generally accepted today between private law and public law.

(2) The liberation of peasants was a prerequisite for land mobilisation and thus for the triumphal march of modern property law with free availability over land and for the expansion of the mortgage as proprietary security right. From a legal point of view, the abolition of serfdom helped to separate private rights in rem to land from duties under public law. It was not until the liberation of the peasants that land charges and servitudes received their clearly defined form known today. In other words, without the abolition of serfdom we would not have a purely private-law system of limited rights in rem to immovable property today.

(3) Finally, the history of private law must challenge the accusation of allegedly antisocial private law. Since legislation and jurisprudence around 1800 separated private law and public law into two clearly distinguishable areas of law with very different legal principles, the social and economic problems associated with the liberation of peasants must not be a priori attributed to private law. It would have been the task of a public social law to mitigate the impoverishment of the rural population. As far as private law is concerned, the liberation of peasants was a great success. The transformation laws put farmers under constant pressure to succeed. This increased output and productivity in agriculture. Only profitable farms were able to survive, all others had to be sold or abandoned altogether. a differentiated view is also required of the continuing burdens on the rural population. Military service replaced forced labour, and tax liability replaced natural levies. The modern state thus had direct access to its citizens by eliminating the landlords as intermediaries and replacing them with the state administration. To a certain extent, the state took over the role of the former landlords.

${ }^{24}$ Blickle P. Von der Leibeigenschaft zu den Menschenrechten. Eine Geschichte der Freiheit in Deutschland. 2nd edition, Munich: Beck, 2006.

25 Overview: Winterberg H., Eckert J. Article Bauernbefreiung. In: Handwörterbuch zur deutschen Rechtsgeschichte, 2nd edition, Vol. 1, Berlin: Erich Schmidt, 2008, cols. 466-470.

26 Hauser A. Die Gesetzgebung zur Herstellung unbeschränkten Grundeigentums und zur Aufhebung der Leibeigenschaft. Der württembergische Weg. Tübingen: Köhler-Druck, 2003, pp. 19 sq., 33. 
Against this background, the social and economic problems of the rural population in the $19^{\text {th }}$ century can only be interpreted as a temporary transitional stage. From the point of view of private law, freedom comes with personal responsibility and the duty of each individual citizen to provide for his or her own subsistence. Where, in the system of serfdom in times of need, the landlord had to feed his serfs and supply them with seed, such tasks were left to the state and thus to public law after the liberation of the peasants. Similarly, the lack of financial resources of the former serfs to discharge old duties cannot be blamed on private law. During a phase of fundamental social reform, only the state can ensure equal starting conditions.

\section{Conclusions}

The abolition of serfdom around 1800 and in the decades that followed was an epochal event for the German-speaking territories. Not only society and agriculture changed fundamentally. From the point of view of modern, liberal private law, the abolition of serfdom can quite rightly be interpreted as the liberation of peasants. This liberation is to be seen in the context of many other measures to liberalise society and law in the transition from the Holy Roman Empire to the German Confederation and later the German Empire. Even today's private law with the separation of personal law, law of obligations and property law, also the concept of an absolute, freely disposable property would be unthinkable without the abolition of serfdom. With the restructuring of private law, today's boundaries between private law and public law have crystallized.

Certain social and economic transformation problems must not be overlooked. However, such problems were no negative effect of the newly won freedom and the modern, liberal private law. By creating formal equality, private law opened up economic opportunities. Public law was responsible for smoothing the hardships associated with this transformation. Such problems were even inevitable when one looks at the entire history of fundamental transformations. They occurred in Germany after the Second World War in the burden-sharing (Lastenausgleich) between the citizens of the states in West Germany and the refugees from the former Eastern territories. The transition from a socialist command economy to a market economy in the former German Democratic Republic also posed numerous similar challenges which are solely attributable to socialist law, not modern, liberal private law.

\section{BIBLIOGRAPHY}

\section{Literature}

1. Andermann K. Art. Leibeigenschaft. In: Handwörterbuch zu deutschen Rechtsgeschichte. Vol. 3. Berlin: Erich Schmidt, col. 771.

2. Blickle P. Von der Leibeigenschaft zu den Menschenrechten. Eine Geschichte der Freiheit in Deutschland. $2^{\text {nd }}$ edition. Munich: Beck, 2006.

3. Coing H. Europäisches Privatrecht. Vol. 2: 19. Jahrhundert. Munich: Beck, 1989. 
4. Dipper C. Die Bauernbefreiung in Deutschland 1790-1850, Kohlhammer: Stuttgart et al., 1980, pp. 50-93.

5. Duve T. $\$ \$ 1$ 1-14, Natürliche Personen, Verbraucher, Unternehmer. In: Historisch-kritischer Kommentar zum BGB. Vol. 1. Tübingen: Mohr, 2003.

6. Freedmann P., Bourin M. (eds.). Forms of Servitude in Northern and Central Europe: Decline, Restsiance, and Expansion. Turnhout: Brepols, 2005.

7. Groß R. Die bürgerliche Agrarreform in Sachsen in der ersten Hälfte des 19. Jahrhunderts. Untersuchung zum Problem des Übergangs vom Feudalismus zum Kapitalismus in der LandwirtschaftWeimar: Hermann Böhlau, 1968.

8. Groß R. Die bürgerliche Agrarreform in Sachsen und die sächsische Oberlausitz. Letopis, Series B, Vol. 14.1, 1967, p. 1.

9. Harnisch H. Kapitalistische Agrarreform und Industrielle Revolution. Agrarhistorische Untersuchungen über das ostelbische Preußen zwischen Spätfeudalismus und bürgerlich-demokratischer Revolution von 1848/49 unter besonderer Berücksichtigung der Provinz Brandenburg Weimar: Hermann Böhlau, 1984.

10. Hauser A. Die Gesetzgebung zur Herstellung unbeschränkten Grundeigentums und zur Aufhebung der Leibeigenschaft. Der württembergische Weg. Tübingen: Köhler-Druck, 2003.

11. Hippel W. Die Bauernbefreiung im Königreich Württemberg. Boppardt am Rhein: Harald Boldt, 1977.

12. Knapp G. F. Die Bauern-Befreiung und der Ursprung der Landarbeiter in den älteren Teilen Preußens. 2 vols. Duncker \& Humblot: Leipzig, 1887.

13. Koselleck R. Preußen zwischen Reform und Revolution. Allgemeines Landrecht, Verwaltung und soziale Bewegung von 1791 bis 1848. Klett: Stuttgart, 1967.

14. Leiser L. Schichtspezifisches Privatrecht. Savigny-Zeitschrift für Rechtsgeschichte. Germanistische Abteilung 93, 1976, p. 1.

15. Paulus C. Ein Plädoyer für unscheinbare Normen. Juristische Schulung, 1994, p. 367.

16. Stolleis M. Historische und ideengeschichtliche Entwicklung des Gleichheitssatzes. In: Gleichheit und Nichtdiskriminierung im nationalen und internationalen Menschenrechtsschutz. Berlin et al.: Springer, 2003, p. 7.

17. Winterberg H, Eckert J. Art. Bauernbefreiung. In: Handwörterbuch zur deutschen Rechtsgeschichte. 2nd edition. Vol. 1. Berlin: Erich Schmidt, 2008, col. 466.

18. Wunder H. Serfdom in Later Medieval and Early Modern Germany. In: Social Relations and Ideas. Essays in Honour of R. H. Hilton. Cambridge: Cambridge University Press, 1983, p. 249.

\section{Normative acts}

1. Edict. Concerning the regulation of the property and peasant relations, 14 September 1811. Collection of Laws for the Royal Prussian States, 1811, p. 281.

2. Rescript. Concerning allodification of fiefdoms. 6 July 1812. Royal Württemberg State and Government Gazette, 1812, 154.

3. Edict. 18t November 1817. Royal Württemberg State and Government Gazette, 1817, appendix.

4. Ordinance.13 September 1818. Royal Württemberg State and Government Gazette, 1818, 503.

5. Act. On Redundancies and Common Divisions. 17 March 1832. Collection of Laws and Regulations for the Kingdom of Saxony, 1832, p. 163. 
6. Order. In reference to the latest compensation laws. 29 October 1836. Government Gazette for the Kingdom of Württemberg, 1836, p. 588.

7. Act. Concerning the removal of charges resting on the land. 14 April 1848. Government Gazette for the Kingdom of Württemberg, 1848, p. 165.

8. Act. Concerning the replacement of tithes. 17 June 1849. Government Gazette for the Kingdom of Württemberg, 1849, p. 181.

9. Act. Concerning the compensation of land charges and the regulation of the landowner's and peasant's relationships. 2 March 1850. Collection of Laws for the Royal Prussian States, 1850, p. 77. 